„TURYZM" 1994, t. 4, z. 2

\title{
Monika Pluta
}

FUNKCJA TURYSTYCZNA ZAMKU KRÓLEWSKIEGO W WARSZAWIE ${ }^{1}$

\section{LA FONCTION TOURISTIQUE DU CHÂTEAU ROYAL À VARSOVIE}

THE TOURIST FUNCTION OF THE ROYAL PALACE IN WARSAW

W pracy podjęto próbę określenia funkcji turystycznej na tle innych działalności spolecznych Zamku Królewskiego w Warszawie. Przyjęto założenie, że miarą tej funkcji jest geograficzny zasięg oddzialywania obiektu. Przeprowadzone badania wykazały międzynarodową rangę Zamku, który będąc obiektem turystycznym pełni jednocześnie bardzo ważną funkcję reprezentacyjną.

1. WSTĘP

Celem badań było określenie znaczenia Zamku Królewskiego w Warszawie jako obiektu turystycznego. W pracy założono, że Zamek Królewski w Warszawie jako obiekt zabytkowy pełni różnorodne funkcje użytkowe, wśród których dominuje funkcja turystyczna, oraz że funkcja ta nadaje mu rangę nie tylko ogólnokrajową, ale również międzynarodową. Weryfikacja tych hipotez została przeprowadzona na podstawie badań walorów turystycznych obiektu, oraz analizy stanu zagospodarowania i jego działalności. Na podstawie bezpośrednich badań ankietowych oraz rocznych sprawozdań udostępnionych przez dział oświatowy Zamku, zbadano wielkość i dynamikę ruchu turystycznego na przestrzeni lat 1981-1992, sezonowość oraz strukturę społeczno-demograficzną, a także zasięg

1 Artykuł opracowano na podstawie pracy magisterskiej pt. Funkcja turystyczna Zamku Królewskiego $w$ Warszawie wykonanej na seminarium z geografii turyzmu w Katedrze Geografii Miast i Turyzmu UŁ w 1993 r. pod kierunkiem prof. dra hab. Stanislawa Liszewskiego. Opiekunem pracy była Pani dr Elżbieta Dziegieć. 
geograficzny odwiedzających Zamek Królewski w Warszawie. Ocenie poddano także subiektywne wrażenia i odczucia turystów, którzy odwiedzili Zamek.

\section{FUNKCJE OBIEKTU}

Wnętrza zamkowe poza funkcją muzealną polegającą na przechowywaniu i udostępnianiu dzieł sztuki dawnej, pełnią także funkcje reprezentacyjne i społeczne. Odbywają się tu bowiem różnorodne spotkania i uroczystości oficjalne. Zamek znajduje się również w programach wizyt dyplomatycznych wielu delegacji państwowych.

Co miesiąc przyjmowanych jest kilkanaście delegacji rządowych na szczeblu głów państw, premierów, ministrów i wiceministrów spraw zagranicznych oraz innych dostojników wysokiej rangi, których obsługą zajmuje się Dział Organizacji Imprez Zamku Królewskiego w Warszawie. W latach 1986-1991 goszczono 751 delegacji. Najwięcej delegacji odwiedziło Zamek w roku 1988 - 171 (rys. 1). Co roku przyjmowanych jest ich ponad $100 \mathrm{z}$ wyjątkiem roku 1991, w którym zanotowano 71 delegacji. Wizyty te nadają wysoką rangę obiektowi, a światowe osobistości goszczące w jego murach potwierdzają międzynarodowe znaczenie Zamku.

Funkcja kulturalno-oświatowa Zamku Królewskiego w Warszawie jest niezwykle bogata i szeroko rozwinięta.

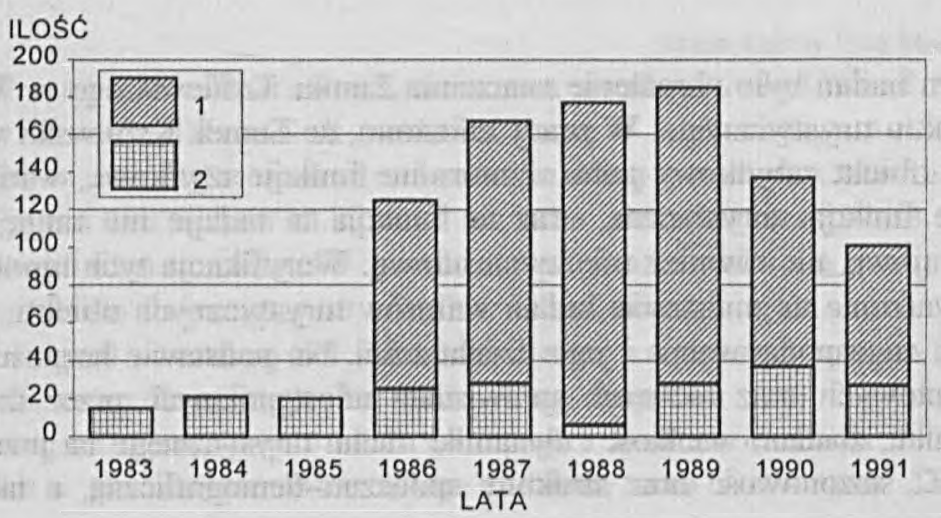

Rys. 1. Liczba koncertów i wizyt oficjalnych delegacji państwowych na Zamku Królewskim w Warszawie w latach 1983-1991

1 - liczba delegacji państwowych; 2 - liczba koncertów

Dessin 1. Le nombre des concerts et des visites officielles des délégations d'état au Château Royal à Varsovie dans les années 1983-1991

1 - le nombre des délégations d'état; 2 - le nombre des concerts 
Zamek, obok ekspozycji stałej organizuje wystawy czasowe. Wystawy te są istotnym elementem życia kulturalnego nie tylko w Warszawie, ale w skali całego kraju. W latach 1981-1991 przygotowano 44 wystawy. Największą frekwencją cieszyła się wystawa z roku 1990 pt. „Opus sacrum”, którą obejrzało 85246 osób, druga w kolejności była wystawa „Polska w okresie Jagiellonów 1384-1572", która odwiedziło 65537 osób. Na trzecim miejscu znalazła się wystawa otwarta w 1989 r. pt. "Srebra Funduszu Obrony Narodowej” - 56407 osób. Ta ostatnia przekształciła się w stałą ekspozycję. Liczba osób odwiedzających wystawy jest dowodem wysokiej rangi obiektu jako centrum wystawienniczego.

Wnętrza Zamku stanowią również bardzo dobre miejsce do organizacji koncertów, które weszły na stałe do programu działalności obiektu towarzysząc m. in. ważnym wydarzeniom czy wystawom. Pierwszy koncert odbył się we wrześniu 1983 r. - był to koncert muzyki dawnej. Niektóre z koncertów odbywają się cyklicznie, jak np. Koncert Mozartowski, czy Festiwal Muzyki Sakralnej. Łącznie w latach 1983-1991 odbyło się 207 koncertów (rys. 1). Średnio odbywają się 23 koncerty w ciągu roku, w czasie których przedstawiony jest bardzo różny repertuar prezentowany przez muzyków zarówno polskich jak i zagranicznych.

Zamek Królewski w Warszawie pelni również funkcję edukacyjną. W roku szkolnym 1983/1984 pracownicy Działu Oświatowego rozpoczęli prowadzenie lekcji muzealnych. Obiekt ten stanowi szczególną pracownię historyczną dla nauczyciela historii, języka polskiego, wiedzy o społeczeństwie, wychowania plastycznego, dla wszystkich typów szkół i klas poczynając od klasy IV szkoły podstawowej.

Lekcje w muzeum mają charakter repetytorium wiedzy przyswojonej przez uczniów, lub stanowią wprowadzenie do tematu omawianego później w szkole. Oprócz lekcji dla szkół podstawowych i średnich prowadzone są zajęcia dla szkół specjalnych i okazjonalnie dla wszystkich kategorii niepełnosprawnych.

Ogółem w latach 1983-1991 odbyło się 4245 lekcji, najwięcej w 1991 r., bo aż 1407. Zdecydowaną przewagę - aż $90 \%$ - mają lekcje dla szkół podstawowych Warszawy i okolic. Powiększająca się z roku na rok liczba lekcji świadczy o tym, jak celowa i potrzebna jest tego typu działalność.

$\mathrm{Z}$ myślą o odwiedzających obiekt w 1985 r. uruchomiono kino zamkowe, w którym prezentowane są filmy dotyczące historii i odbudowy Zamku. Często filmy wykorzystywane są do lekcji czy też towarzyszą wystawom.

Przegląd ten dowodzi bogactwa form działalności Zamku Królewskiego w ramach funkcji kulturalno-oświatowej. Niewątpliwie działalność lekcyjna, koncertowa i kinowa skierowana jest głównie do mieszkańców Warszawy i województwa warszawskiego. Jedynie z wystaw eksponowanych przez kilka miesięcy korzystają turyści z całej Polski.

Zamek Królewski w Warszawie jest niezwykle ważną i znaczącą skarbnicą wiedzy o historii i kulturze narodu polskiego (S z y p o w s c y 1989). Wnętrza, zbiory dzieł sztuki i zabytków kultury narodowej nadają mu rangę obiektu o istotnym znaczeniu dla turystyki. 
3. WIELKOŚĆ, SEZONOWOŚĆ I STRUKTURA SPOLECZNO-DEMOGRAFICZNA RUCHU TURYSTYCZNEGO

Miarą atrakcyjności turystycznej obszaru czy obiektu jest występowanie i wielkość ruchu turystycznego (W a r s z y ń s ka, J a c kow s k i 1979). W okresie od września 1981 do września 1982 r. Zamek odwiedziło 3944765 osób. Przez pierwsze cztery lata, gdy Zamek udostępniony był tylko częściowo, rejestrowany ruch turystyczny wynosił około 200 tysięcy osób rocznie z wyjątkiem roku 1981, który był pierwszym rokiem działania i w którym zanotowano tylko 33637 osób. Natomiast rok 1985, w którym udostępniono wszystkie wnętrza odznaczał się największą frekwencją w historii Zamku - 474884 osoby. W latach 1985-1988 ruch turystyczny utrzymywał się na dość wyrównanym poziomie (rys. 2). To duże zainteresowanie spowodowane jest szczególną atrakcyjnością obiektu, który oprócz walorów artystycznych jest dla Polaków symbolem trwałości i niepodległości państwa, symbolem siły odrodzeńczej narodu, który wielokrotnie podnosił się z klęski (S z y p o w s c y 1989).

Od roku 1989 obserwujemy systematyczny spadek frekwencji. Mają na to wpływ nasycenie i zaspokojenie potrzeb, podwyżki cen biletów oraz stopniowe ubożenie społeczeństwa.

Wśród ogromnej liczby gości, którzy odwiedzili Zamek, obok Polaków, znajdują się turyści zagraniczni. Stanowią oni dość znaczną liczbę wśród odwiedzających, jednak jej ustalenie jest trudne, gdyż nie prowadzi się oddzielnych

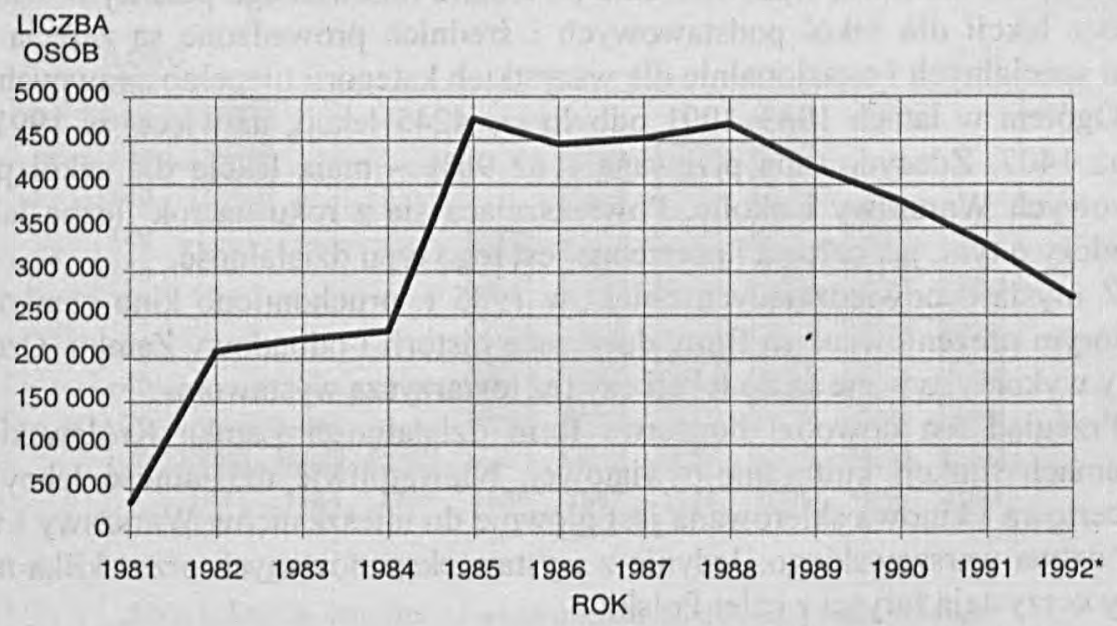

Rys. 2. Wielkość ruchu turystycznego w Zamku Królewskim w Warszawie w latach 1981-1992 (dane do września 1992 r.)

Dessin 2. La grandeur du mouvement touristique au Château Royal à Varsovie dans les années 1981-1992 (septembre inclus) 
statystyk. Wyniki badań ankietowych przeprowadzonych przez autorkę w lipcu 1992 r. wykazały obecność 391 osób pochodzących z zagranicy, co stanowiło $33 \%$ wszystkich ankietowanych. Można przypuszczać, że udział wszystkich turystów zagranicznych w ruchu turystycznym jest większy, gdyż ankiety przeprowadzone zostały losowo i nie objęły wszystkich obcokrajowców odwiedzających w tym okresie Zamek.

Ruch turystyczny w Zamku Królewskim w Warszawie rozkłada się nierównomiernie. W skali roku w badaniach sezonowości obiektu posłużono się materiałami dotyczącymi ilości sprzedanych biletów w poszczególnych miesiącach. Do analizy został wybrany okres od stycznia 1990 r. do września 1992 r. Na podstawie zebranych materiałów obliczono wskaźnik sezonowości (K a c zm a r e k, L i s z e w s k i 1989). Z analizy tego wskaźnika wynika, że w ciągu roku główny ruch turystyczny w Zamku trwa od kwietnia do października. Pozostały okres (listopad-marzec)) uznać możemy za sezon przejściowy. Nie stwierdzono w badanym obiekcie sezonu martwego. Dużą frekwencja odznacza się maj, od 117,0 do $134,4 \%$, jako że jest to miesiąc wycieczek szkolnych, natomiast w czerwcu wskaźnik ten zawsze spada ze względu na okres egzaminów i koniec roku szkolnego. Podobna sytuacja występuje we wrześniu. Natomiast w lipcu i sierpniu wskaźniki są najwyższe $126,0-145,7 \%$ (rys. 3). Najniższe wartości w badanym obiekcie występują w grudniu, styczniu i lutym - od 42,7 do

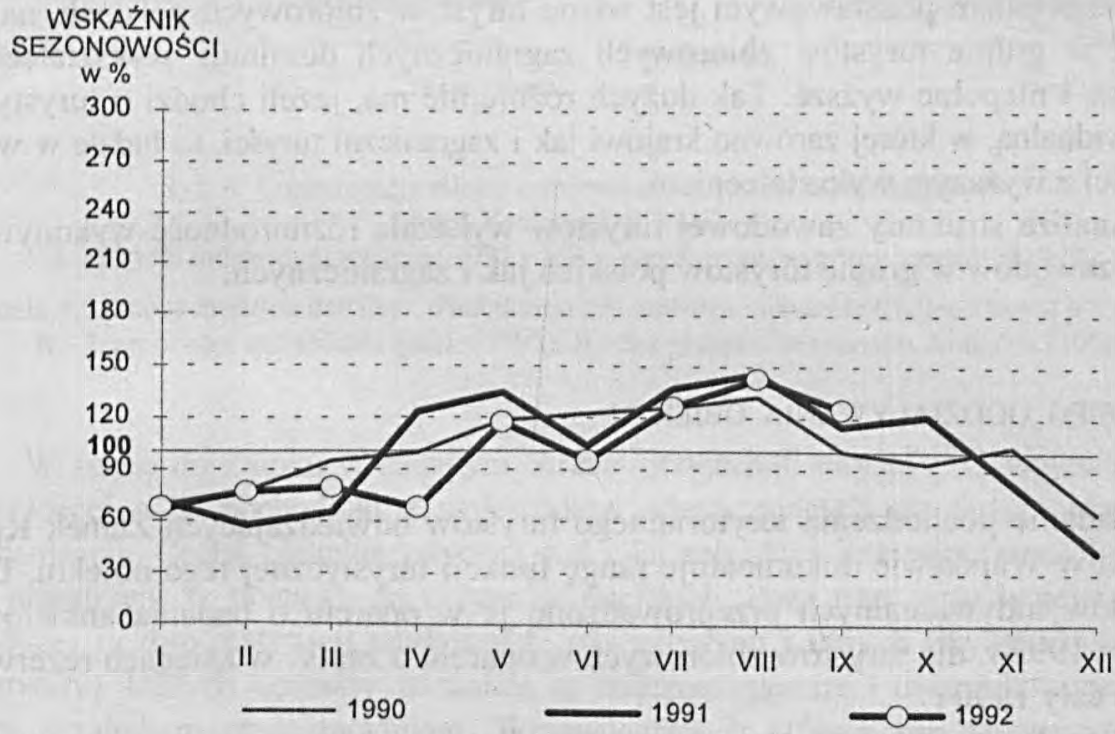

Rys. 3. Sezonowość ruchu turystycznego na Zamku Królewskim w Warszawie w latach 1990-1992 (do września włącznie)

Dessin 3. La caractère saisonnier du mouvement touristique au Château Royal à Varsovie dans les années 1990-1992 (septembre inclus) 
$65,0 \%$. Są to miesiące zimowe nie sprzyjające odbywaniu wycieczek, z wieloma dniami świątecznymi.

Wśród odwiedzających Zamek w lipcu $1992 \mathrm{r}$. badaniom ankietowym poddano 1181 osób. Było wśród nich 681 kobiet $(57,6 \%)$ i 500 mężczyzn $(42,4 \%)$. W grupie Polaków zdecydowanie przeważały kobiety $59 \%$, co w przybliżeniu odpowiada strukturze płci społeczeństwa polskiego. Również wśród turystów zagranicznych występowało więcej kobiet niż mężczyzn.

Struktura wiekowa badanej grupy turystów była zróżnicowana, można stwierdzić, że Zamek zwiedzają wszyscy, od dzieci po emerytów. Wśród turystów indywidualnych największy odsetek $(49,8 \%)$ stanowily osoby dorosłe, natomiast wśród uczestników wycieczek zbiorowych dominowały dzieci stanowiące aż $61,4 \%$. Znikomy procent wśród badanych to emeryci i studenci (okres wakacji letnich).

Ważną cechą społeczno-demograficzną ruchu turystycznego jest struktura wykształcenia. Ogólnie można stwierdzić, że wśród badanych dominowały osoby bez ukończonej szkoły podstawowej - 426 osób (36,4\%). Z wykształceniem wyższym odnotowano 309 osób $(26,4 \%)$, a najmniej z wykształceniem zasadniczym zawodowym - $14(1,2 \%)$ i policealnym -32 osoby $(2,7 \%)$. Dzieląc badaną populację na turystów indywidualnych i zbiorowych przewaga wykształcenia wyższego występuje wśród turystów indywidualnych zarówno polskich jak i zagranicznych. Najwięcej ludzi bez ukończenia szkoły podstawowej i z wykształceniem podstawowym jest wśród turystów zbiorowych polskich, natomiast $\mathrm{w}$ grupie turystów zbiorowych zagranicznych dominuje wykształcenie wyższe i niepełne wyższe. Tak dużych różnic nie ma, jeżeli chodzi o turystykę indywidualna, w której zarówno krajowi jak i zagraniczni turyści, to ludzie w większości z wyższym wykształceniem.

Analiza struktury zawodowej turystów wykazała różnorodność wykonywanych zawodów w grupie turystów polskich jak i zagranicznych.

\section{ZASIĘG ODDZIAŁYWANIA OBIEKTU}

Badanie pochodzenia terytorialnego turystów odwiedzających Zamek Królewski w Warszawie dokumentuje rangę funkcji turystycznej tego obiektu. Dla turystów indywidualnych przeprowadzono je w oparciu o badania ankietowe z lipca 1992 r. dla turystów zbiorowych w oparciu o zapisy w księgach rezerwacji za cały $1990 \mathrm{r}$.

Współczynnik koncentracji wyliczony dla ruchu turystycznego indywidualnego jest znaczny i wynosi 0,75 , świadcząc o ograniczonej grupie województw, z których pochodziły osoby indywidualnie odwiedzające Zamek. Najwięcej z grupy badanych turystów, bo aż $31,6 \%$ pochodziło z Warszawy i województwa stołecznego warszawskiego (rys. 4a). Następne w kolejności województwa 
o dużej liczbie turystów to łódzkie i gdańskie, a dalej katowickie, kieleckie i szczecińskie. Osoby przybyłe $\mathrm{z}$ tych pięciu województw stanowiły $35,5 \%$ wszystkich turystów, a razem $\mathrm{z}$ Warszawą $\mathrm{i}$ województwem warszawskim $67,5 \%$. W czwartej grupie znalazło się 6 województw: krakowskie, ciechanowskie, legnickie, lubelskie, tarnobrzeskie, poznańskie. Pozostałe województwa notowane były w badanym obiekcie tylko śladowo.
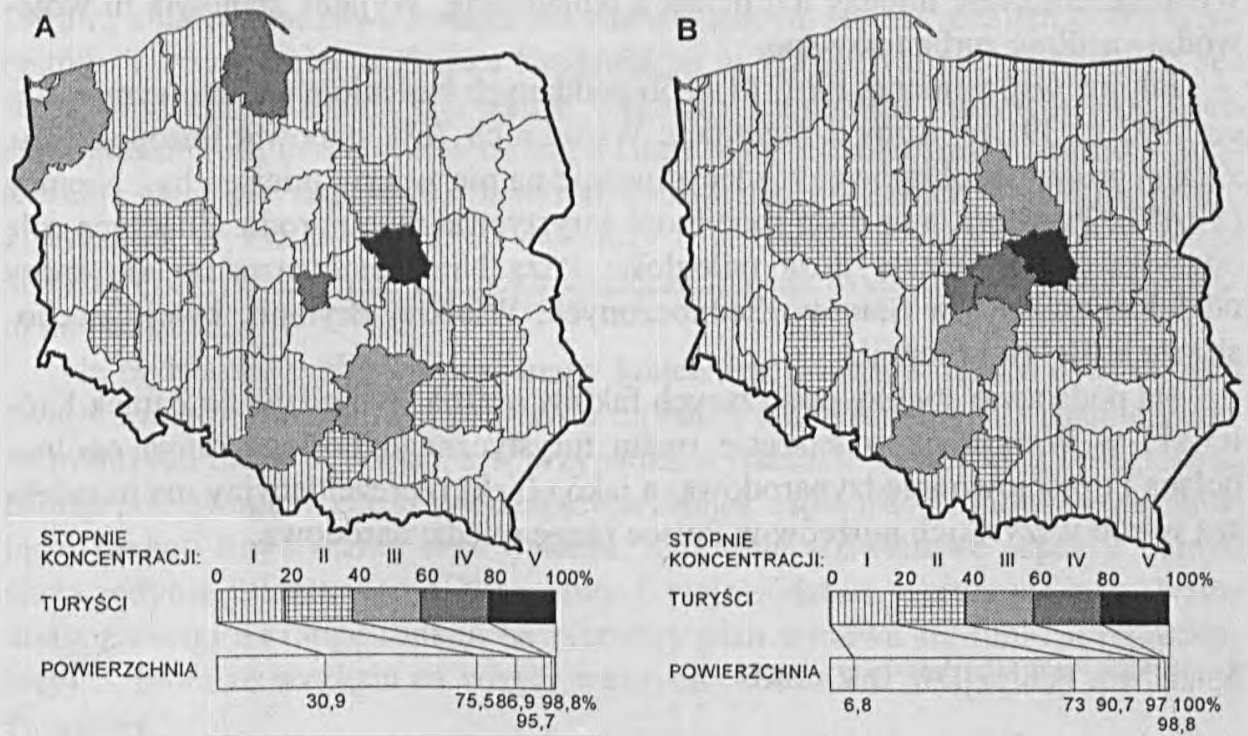

Rys. 4. Koncentracja miejsc zamieszkania turystów odwiedzających Zamek Królewski w Warszawie

A - turyści indywidualni (lipiec 1992 r.); B - zorganizowane grupy turystów (1990 r.)

Dessin 4. La concentration des lieux d'habitation des touristes visitant le Château Royal à Varsovie A - les touristes individuels (juillet 1992); B - les groupes de touristes étrangers (1990)

W sumie do Zamku w badanym okresie przyjechali turyści z 33 województw. Najwięcej osób pochodziło $\mathrm{z}$ województw odznaczających się dużym stopniem urbanizacji. Cechą charakterystyczną ludności miejskiej jest większa ruchliwość w przestrzeni w stosunku do obszarów miejskich. Poza tym są to województwa o dużej liczbie instytucji naukowych, oświatowych i innych (wyższe uczelnie, instytuty), których kontakty ze stolicą są znacznie częstsze i uwarunkowane również względami organizacyjnymi. Województwa, z których nie zanotowano ruchu turystycznego to głównie tereny rolnicze mało zurbanizowane o przewadze małych miejscowości i wsi, często słabo skomunikowane z Warszawą.

Współczynnik koncentracji wyliczony dla turystów zbiorowych na podstawie księgi rezerwacji z 1990 r. (zapis dotyczy grupy a nie indywidualnych 
osób) jest również duży i wynosi 0,73 . Najwięcej wycieczek przyjechało w tym roku z trzech województw: warszawskiego, łódzkiego i skierniewickiego (rys. 4b). Następne w kolejności są: katowickie, ciechanowskie, piotrkowskie. W sumie z 6 wymienionych województw przyjechało $61,4 \%$ wycieczek. Im dalej oddalone województwo, tym mniej wycieczek z niego przyjechało. Większość wycieczek stanowiły grupy szkolne $\mathrm{z}$ województw ościennych, które przyjeżdżały na 1 dzień do Warszawy. Nasuwa się wniosek, że w przypadku wycieczek istnieje wyraźna zależność między ich liczbą a odległością. Wyjątek stanowią tu województwa silnie zurbanizowane.

Jak już wspomniano, na 1181 osób poddanych badaniom ankietowym w lipcu 1992 r., 391 to osoby z zagranicy. Wśród nich 76\% stanowią Europejczycy. $Z$ całej grupy obcokrajowców zdecydowanie na pierwszym miejscu byli Niemcy $(37,4 \%)$. Potwierdza to dużą mobilność turystyczną tego narodu. Znaczącą rolę odgrywa także niezbyt duża odległość. Poza Niemcami zaznacza się spory udział mieszkańców Stanów Zjednoczonych, Wielkiej Brytanii, byłej Czechosłowacji, Belgii i Francji.

Na podstawie analizy powyższych faktów można stwierdzić, że Zamek Królewski w Warszawie w zakresie ruchu turystycznego posiada rangę ogólnopolską i częściowo międzynarodową, a jako obiekt reprezentacyjny ma największą wśród wszystkich muzeów w Polsce rangę międzynarodową.

\section{OPINIA TURYSTÓW O ZAMKU}

$\mathrm{Na}$ wrażenia $\mathrm{z}$ wizyty w Zamku Królewskim w Warszawie w dużej mierze wpływają czynniki subiektywne odwiedzających. O tym, co podoba się najbardziej, decyduje na ogół indywidualny gust, poczucie smaku, a także wiedza i przygotowanie. Prowadząc badania ankietowe w lipcu 1992 r. starano się uzyskać od osób opuszczających Zamek odpowiedź na pytanie: „które z muzealnych wnętrz podobały się Panu(i) najbardziej?”. Okazało się, że największe uznanie wśród turystów krajowych uzyskał Apartament Królewski - 30,9\% i Apartament Wielki - 23,8\%. Natomiast na inne wnętrza zwrócono uwagę w mniejszym stopniu. Wśród turystów zagranicznych na pierwszym miejscu znalazł się również Apartament Królewski - 50\%, a następnie Wielki. O takiej kolejności zadecydowało z pewnością bogactwo i różnorodność wyposażenia wnętrz, które zostały zrekonstruowane $\mathrm{z}$ wielkim przepychem: złoto, kryształy, marmury, lustra, co robi wrażenie na oglądających (S z y p o w s c y 1989). Specyficzny wystrój mają Sale Sejmowe, które są o wiele bardziej interesujące dla Polaków rozumiejących ich znaczenie, niż dla cudzoziemców. Niewątpliwie jednak Zamek Królewski w Warszawie robi wrażenie na oglądających, czego dowodem może być fakt, że na 1181 ankietowanych 1020 wyraziło chęć odwiedzenia go w przyszłości jeszcze raz. 
Wypowiedzi wybitnych historyków sztuki, a także wpisanie Zamku w roku 1981 na listę Pomników Światowego Dziedzictwa dowodzą, że obiekt ten posiada istotne dla kultury polskiej i światowej wartości artystyczne i historyczne. Usytuowanie Zamku na terenie Starego Miasta znacząco wpływa na jego atrakcyjność. W zmienności ruchu zaznacza się wyraźna tendencja wzrostowa do 1988 r., a dalej spadkowa związana z zaznaczającym się nasyceniem potrzeb turystów. Tym niemniej w Zamku Królewskim w Warszawie nie stwierdzono sezonu martwego. Badania ankietowe wykazały niewielkie zróżnicowanie cech demograficznych uczestników ruchu, a także małe zróżnicowanie struktury społecznej. Daje się zauważyć, iż wśród zwiedzających Zamek dominują osoby z wyższym wykształceniem, co świadczy o celowości i świadomym wyborze obiektu. Pozytywne opinie o Zamku świadczą o właściwym oddziaływaniu obiektu na odbiorcę.

Na podstawie wyliczeń oraz mapy koncentracji można mówić o wyraźnym związku między natężeniem przyjazdu turystów indywidualnych a rozmieszczeniem dużych miast w Polsce, a w przypadku wycieczek o związku z odległością. Biorąc pod uwagę liczbę odwiedzających Zamek osób, można mówić o dominującej funkcji turystycznej tego obiektu. Kulturalno-oświatowe aspekty Zamku służą jedynie mieszkańcom Warszawy i województwa warszawskiego. Natomiast $\mathrm{z}$ uwagi na rangę funkcji na pierwszy plan wysuwa się funkcja reprezentacyjna, która ze względu na wizyty ważnych osobistości z zagranicy ma zasięg światowy.

\section{PIŚMIENNICTWO}

K a c z m a re k S., L i s zew s k i S., 1989, Funkcja turystyczna Kartuz, Turyzm 5.

Szypowscy M. i A., 1989, Warszawski Zamek Królewski. Zamek Rzeczypospolitej, Warszawa.

Wa r s y ńs k a J., J a c kow s k i A., 1979, Podstawy geografii turyzmu, Warszawa.

Mgr Monika Pluta

ul. Lanowa 12 m. 23

Wplynęło:

91-103 Łódź

15 czerwca $1994 \mathrm{r}$.

\section{RÉSUMÉ}

Les recherches faites avaient pour but la détermination de l'importance du Château Royal à Varsovie en tant que objet touristique. Les intérieurs du Château, leur fonction de musée mise à part, accomplissent les fonctions représentatives, sociales et de propagation des lumières. Le 
service des délégations d'état met cet objet au haut rang. La fonction culturelle du Château comprend les concerts, les expositions et les leçons de musée, tout cela organisé là-dedans. Cependant ce sont avant tout les habitants de Varsovie et la voïvodie de Varsovie qui en profitent.

La grandeur du mouvement touristique témoigne du rôle dominant de la fonction touristique. Le grand intérêt qu'incite l'objet, découle de son attraction; le Château, outre ses valeurs artistiques, est pour les Polonais le symbole de la stabilité et de l'indépendence de l'état. La disposition du mouvement touristique subit des oscillations. Son apogée a lieu en été. Les autres mois, c'est la saison passagère.

Les recherches d'enquête (juillet 1992) ont démontré la différenciation minime des traits dé mographiques et sociaux des participants du mouvement. L'étendue géographique des visiteurs du Château témoigne de la corrélation entre le tourisme individuel et la disposition de grandes villes, d'une part et le tourisme collectif et l'éloignement de Varsovie, de l'autre. Selon les visiteurs les Appartements: Royal et Grand font la plus grande impression. Prenant en considération le nombre des personnes visitant le Château, on peut dire, que le rôle de la fonction touristique est dominant. Cependant du point de vue des rangs, c'est la fonction représentative qui dévance les autres. Eu égard au service des délégations d'état et des visites diplomatiques, elle a l'étendue mondiale. En accomplissant une véritable fonction représentative dans le protocole diplomatique international, le Château Royal de Varsovie est un objet de grande importance.

Traduit par Lucjan Kowalski

\section{SUMMARY}

The objective of the research was the evaluation of the importance of the Royal Palace in Warsaw as a place of tourist interest. Apart from being a museum, the interiors of the Palace perform representative, social and educational functions. Service to state delegations gives a high standing to this place. The social and educational function consists in concerts, exibitions and museum talks organized in the Palace. This function, however, is important mainly for the inhabitants of Warsaw and the Warsaw voievodship. The tourist traffic in the Palace proves the predominant tourist function.

The great interest in the Palace results from its attractiveness. Apart from being a piece of art in itself, for Polish people it also is a symbol of perseverance and independance of the nation. Tourist traffic is uneven throughout the year. Its peak falls on summer months. The remaining period can be treated as a transient season.

A survey (1992) shoved a slight differentiation of the demographic and social features of the people in the tourist traffic. The geographical range of the visitors in the Palace proves a correlation between individual tourism and the distribution of large cities in Poland, as well as between collective tourism and the distance from Warsaw. In the view of the visitors, the Royal and the Grand Apartments are the most impressive. Considering the number of the visitors in the Palace, one can speak of the predominant tourist function. On the other hand, considering the status of the functions, the representative one takes the lead, as by service to state delegations and diplomatic visits it acquires international importance. The Royal Palace in Warsaw is an important place of tourist interest, which plays a significant representative role in the international diplomatic protocol. 